\title{
A New Biochemical Marker for the Differential Diagnosis of Epileptic Seizure Types: Ischaemia-modified Albumin
}

\section{Epileptik Nöbet Tiplerinin Ayırıcı Tanısında Yeni Biyokimyasal Belirteç: İskemi Modifiye Albümin}

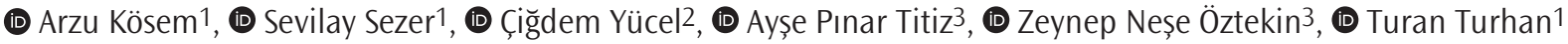 \\ ${ }^{1}$ Ankara City Hospital, Clinical Biochemistry Laboratory, Ankara, Turkey \\ 2University of Health Sciences Turkey, Gülhane Training and Research Hospital, Clinic of Medical Biochemistry, Ankara, Turkey \\ ${ }^{3}$ Ankara City Hospital, Clinic of Neurology, Ankara, Turkey
}

\begin{abstract}
Introduction: This study aimed to evaluate the changes in ischaemia-modified albumin (IMA) levels in different types of hypoxia-associated epileptic seizures.

Methods: A total of 80 patients admitted to the Neurology Outpatient Clinic in Ankara Numune Training and Research Hospital and 103 controls were included in the study. The patients were divided into two groups in terms of the seizure type, including seizures with partial and secondary generalisation and primary generalised seizures. Additionally, patients were classified in terms of the duration between the initial diagnosis and admission. The levels of IMA, albumin and uric acid were analysed by spectrophotometry and comparisons between the groups were performed.
\end{abstract}

Results: IMA levels and IMA/Albumin index values were higher in the patient group than in the control group $(p<0.05$; $p<0.01$, respectively). Regarding the evaluation of the seizure types, IMA and IMA/Albumin index levels were mainly higher in patients with primary generalised seizures $(p<0.05)$. Moreover, these parameters were significantly increased in proportion to the duration of diagnosis.

Conclusion: IMA and IMA/Albumin index may enable clinicians to differentiate the types of epilepsy.

Keywords: Albumin, epileptic seizures, uric acid
ÖZ

Amaç: Bu çalıșmanın amacı, hipoksi ile ilişkili farklı epileptik nöbet tiplerinde iskemi-modifiye albümin (IMA) seviyelerindeki değișiklikleri araștırmaktır.

Yöntemler: Çalışmaya Ankara Numune Eğitim ve Araștırma Hastanesi Nöroloji Polikliniği'ne başvuran toplam 103 kiși kontrol, 80 hasta dahil edildi. Hastalar parsiyel ve sekonder jeneralize nöbet ve primer jeneralize nöbet olmak üzere iki gruba ayrıldı. Ayrıca, hastalar ilk tanı ve başvuru arasındaki süre açısından sınıflandırıldı. IMA, albümin, ürik asit düzeyleri spektrofotometrik olarak analiz edildi ve gruplar arasında karşılaştırmalar yapıldı.

Bulgular: Hasta grubunda IMA düzeyleri ve IMA/Albümin indeks değerleri kontrol grubundan daha yüksekti (sırasıyla, $p<0,05 ; \quad p<0,01)$. Nöbet tiplerinin değerlendirildiğinde primer jeneralize nöbeti olan hastalarda IMA ve iMA/albümin düzeyleri anlamlı olarak yüksek bulundu $(p<0,05)$. Ayrıca, bu parametreler tanı alındığı dönemde önemli ölçüde artmıştır.

Sonuç: Sonuç olarak, IMA ve IMA/Albümin indeksi klinisyenlerin epilepsi türlerini ayırt etmelerine yardımcı olabilir.

Anahtar Kelimeler: Albümin, epileptik nöbet, ürik asit

\section{Introduction}

Epilepsy is a chronic neurological disease that requires long-term treatment. Numerous studies have focused on the role of oxidative stress in the pathogenesis of atherosclerosis and some psychiatric and neurodegenerative disorders (1).

In comparison to antioxidant levels, an increase in the formation of free radicals is regarded as an important contributing factor to the pathogenesis of various diseases caused by oxidative injury $(2,3)$. Free radicals can play a role in the exacerbation of some types of seizure. The most investigated oxidative damage markers have been lipid peroxidation end products, protein carbonyl groups and nitric oxide. Animal studies using seizure models have provided evidence of increased oxidative stress (elevated lipid peroxidation and protein carbonylation) after seizures (4).
Address for Correspondence/Yazıșma Adresi: Arzu Kösem MD, Ankara City Hospital, Clinical Biochemistry Laboratory, Ankara, Turkey

Phone: +90 5058661268 E-mail: arzukosem@gmail.com 0RCID ID: orcid.org/0000-0002-6213-1749

Cite this article as/Atıf: Kösem A, Sezer S, Yücel Ç, Titiz AP, Öztekin ZN, Turhan T. A New Biochemical Marker for the Differential Diagnosis of Epileptic Seizure Types: Ischaemia-modified Albumin. İstanbul Med J 2020; 21(6): 477-480.

(c) Copyright 2020 by the University of Health Sciences Turkey, Istanbul Training and Research Hospital/istanbul Medical Journal published by Galenos Publishing House.

(C) Telif Hakkı 2020 Sağlık Bilimleri Üniversitesi istanbul Ĕgitim ve Araştırma Hastanesi/Istanbul Tıp Dergisi, Galenos Yayınevi tarafından basılmıștır.
Received/Geliș Tarihi: 17.02.2020 Accepted/Kabul Tarihi: 20.10.2020 
Oxidative stress due to Reactive Oxygen Substance formation plays a role in ischaemia- and reperfusion-induced neuronal damage. In addition, plasma antioxidant activity can be an essential component in protecting against neuronal impairments induced by stroke-related oxidative stress (5). Ischaemia-modified albumin (IMA) is considered as a comparatively new biomarker for ischaemia as it has been extensively investigated in various types of ischaemic disorders (6). This biomarker is a variant of the metabolic protein produced in acute ischaemic situations as a result of the reduction in the albumin binding capacity for transition metals such as cobalt, nickel and copper (7-9). While ischaemia and reperfusion occur, the modification that changes the binding capacity of albumin to transition metals can also occur as a result of oxidative stress $(10,11)$. Secondary physiological changes (including hypotension, hypoxia, hypoglycaemia and hyperthermia) that occur as the length of epileptic seizures increases contribute to injury both in the brain and other organs (12).

The recent finding that ischaemia causes changes in serum albumin structure has facilitated the development of a new marker for ischaemia. The last amino acid terminal in the albumin structure has the ability to bind heavy metals such as copper, nickel and cobalt. Factors such as hypoxia, acidosis and free radical damage occurring during ischaemia lead to the reduced binding of these metals to the N-terminus of albumin. This albumin with an altered structure is described as IMA. For the biochemical analysis of various diseases such as ischaemic heart disease, deep vein thrombosis, pulmonary embolism, mesenteric ischaemia and cerebrovascular events, the aforementioned protein level was investigated and its level was found to be above the normal level $(9,13)$. Anaerobic metabolism resulting from decreased blood supply in the hypoxic ischaemic region leads to the formation of free oxygen radicals through the reduction of free metals and the catalytic effect of the superoxide dismutase enzyme, which results in increased IMA levels in the blood.

Animal studies have shown that the use of antioxidants in addition to anticonvulsants led to both a decrease in oxidative stress and frequency of seizures. The complex mechanism of epileptogenesis still remains unclear. However, factors causing neuronal death, which is a key element, may play an important role in the disease progression. Indeed, oxidative stress due to free radicals has been shown to cause mitochondrial dysfunction and cell death. In addition, this study aimed to evaluate the oxidative stress in patients with epilepsy who are not using any antiepileptic drug (AED) and the effects of AEDs in those taking a monodrug or multidrug therapy (14).

This study aimed to evaluate the changes in plasma IMA levels in two types of epileptic episodes in an age- and sex-matched control group.

\section{Methods}

A total of 80 patients admitted to Ankara Numune Training and Research Hospital Clinic of Neurology and 103 controls were included in the study. The patients were classified into two groups in terms of the seizure type, including seizures with partial and secondary generalisation and primary generalised seizures. Furthermore, the time interval between the initial diagnosis and admission time was categorised.
The controls consisted of $47(45.6 \%)$ males (47.6 \pm 8.3 years) and 56 (54.4\%) females ( $42.7 \pm 7.6$ years) (Table 1$)$ while the epilepsy patients consisting of 38 males (47.5\%) (49.3 \pm 9.4$)$ and 42 females $(52.5 \%)$ (47.2 \pm 8.3 years) (Table 1). While $10 \%$ of the patients were untreated, $52.5 \%$ of them were receiving a monotherapy (24.6\% carbamazepine, $42.6 \%$ phenytoin, $14.8 \%$ valproate, $18 \%$ others) and $37.5 \%$ were receiving a polytherapy (Table 2). The demographics and epilepsy profiles of the participants are shown in Table 2. IMA, albumin and uric acid levels were analysed using spectrophotometric methods. Ankara Numune Training and Research Hospital Ethics Committee with protocol number: 17-1439 (date: 05.07.2017). Informed volunteer consent was obtained from each patient.

\section{Measurement of Serum Ischaemia-modified Albumin Levels}

Serum IMA levels were measured using the colorimetric method described by Bar-Or et al. (8). In this method, $200 \mu \mathrm{L}$ serum was added into $50 \mu \mathrm{L}$ cobalt chloride solution $0.1 \%(\mathrm{w} / \mathrm{v})$ and stirred gently for 10 minutes for sufficient albumin-cobalt binding reaction to occur. Then, $50 \mu \mathrm{L}$ of dithiothreitol $\left(1.5 \mathrm{mg} / \mathrm{mL} \mathrm{H}_{2} \mathrm{O}\right)$ was added as a colouring agent. After 2 minutes of incubation, $1.0 \mathrm{~mL}$ of $0.9 \% \mathrm{NaCl}$ was added to terminate the reaction. The colour change was then measured at 470 nm using a spectrophotometer (Hitachi U-2900 Spectrophotometer). Measurement results were reported as Absorbance Unit. Serum albumin was detected with the Bromcresol-Green method in a calibrated and well controlled autoanalyser. IMA/Albumin index and albumin-adjusted IMA were calculated using the following equations:

IMA/Albumin index = IMA/Albumin

Albumin-adjusted IMA $=($ Albumin/Median of Albumin $) \times I M A$

\section{Statistical Analysis}

Statistical analysis was conducted using SPSS version 20 and MS Excel. The continuous variables are presented as mean \pm standard deviation, while categorical data are presented as percentages. The differences between two continuous variables was analysed by Student's Unpaired t-test, while ANOVA test was preferred for the detection of the differences between different groups. The relationship between the variables were assessed by Pearson's correlation coefficient. A $p$ value of $<0.05$ was considered statistically significant.

\section{Results}

Eighty patients with epilepsy and 103 healthy controls, who were matched in terms of age and sex, were included in this study. Serum IMA, uric acid and albumin values are shown in Tables 1 and 2. Compared to the control group, a highly significant increase in the serum IMA levels $(p<0.05)$ of patients with acute epilepsy was detected, while there was a significant decrease in endogenous antioxidants such as uric acid $(p<0.05)$ and albumin $(p<0.05)$ in epileptic patients. Furthermore, a significant negative correlation between serum IMA and serum uric acid $(r=-0.237, p<0.05)$ was detected. IMA levels were negatively correlated but not statistically significant between treatment groups and disease duration ( $r=-0.40, p>0.05 ; r=-0.168, p>0.05$, respectively). 
IMA levels, IMA/Albumin index and Albumin-adjusted IMA values were higher in the patient group compared to the control group $(p<0.05$; $p<0.01 ; p<0.05$, respectively) (Table 1 ). In terms of seizure types, IMA, IMA/Albumin index and Albumin-adjusted IMA levels were significantly higher in patients with primary generalised seizures $(p<0.05)$ (Table 2). In addition, IMA levels were significantly increased in proportion to the duration of the diagnosis. It was detected that the median duration of disease in the patient group was 7 (1-13) years. There was no difference between genders in terms of the disease duration.

\section{Discussion}

Anaerobic metabolism resulting from decreased blood supply in the hypoxic ischaemic region leads to the formation of free oxygen radicals by the reduction of free metals and catalytic effect of the superoxide dismutase enzyme, which results in increased blood IMA levels.

Many investigations have demonstrated that the formation of free radicals, which lead to oxidative stress, plays a significant role in the pathogenesis of epileptic diseases. Various factors make brain tissue susceptible to the detrimental impact of free radicals. Cerebral cell membrane lipids are particularly abundant in polyunsaturated fatty acid side chains, which are extremely sensitive to free radical damage $(15,16)$. IMA, formerly investigated in patients with acute chest pain, is a non-specific tissue ischaemia marker that has been shown to increase spontaneously in epileptic patients (13).

\begin{tabular}{|c|c|c|c|}
\hline & $\begin{array}{l}\text { Patients } \\
(\mathrm{n}=80)\end{array}$ & $\begin{array}{l}\text { Control } \\
(n=103)\end{array}$ & $p$ \\
\hline Male (N, \%) & 38 (47.5) & 47 (45.6) & 0.051 \\
\hline IMA (ABSU) & $0.668 \pm 0.135$ & $0.597 \pm 0.183$ & 0.027 \\
\hline IMA/albumin & $0.162 \pm 0.038$ & $0.128 \pm 0.045$ & 0.005 \\
\hline Albumin-adjusted IMA & $0.654 \pm 0.137$ & $0.585 \pm 0.144$ & 0.025 \\
\hline Albumin (g/dL) & $4.11 \pm 0.43$ & $4.65 \pm 0.37$ & 0.023 \\
\hline Uric acid (mg/dL) & $4.19 \pm 0.83$ & $4.77 \pm 1.06$ & 0.042 \\
\hline
\end{tabular}

Particularly, in patients with hypoalbuminemia, IMA/Albumin index and albumin-adjusted IMA levels are more valuable than IMA levels. Therefore, we included these parameters in our study. The albumin levels were decreased in the patient group compared to the control group.

According to the results of most previous studies involving patients receiving treatment, it was not shown that oxidative stress was due to epilepsy or AEDs. On the other hand, some studies comparing treated and untreated patients showed no difference (17-19). According to the results of these studies as well as those of our study, the role of AEDs in increasing oxidative stress is not significant. These outcomes have therapeutic consequences.

Although this study contributes to the current literature data, a more thorough investigation is required to understand the mechanism of epilepsy in order to offer newer methods of disease modification. Furthermore, it was concluded in this study that elevated IMA levels with increased severity and duration of epilepsy have the potential to help clinicians in determining the type of epilepsy.

As a limitation, this study was performed among cases with no markers of hypoxia following seizure (no acidosis, oxygen saturation $>90 \%$ ). In addition, acute phase proteins were not measured.

\section{Conclusion}

Oxidative markers were found to be increased in the epileptic patients in this study. The finding that the AEDs did not affect the oxidative markers indicates that the oxidative stress was caused by seizures. However, the underlying mechanism of epileptogenesis is still unknown. Although new AEDs have been identified, most of them are refractory to therapy. Therefore, it is necessary to have new treatment modalities, including AEDs with a potential supplementary antioxidant therapy. In addition to the inclusion of new results in the current literature, more detailed studies are required to analyse the mechanism of epilepsy.

We can conclude that IMA is a simple, non-invasive approach to evaluate the oxidative stress in clinical practice, although without other inflammatory markers, IMA alone may not inform physicians about the

Table 2. Serum IMA, uric acid and albumin values in the patient groups

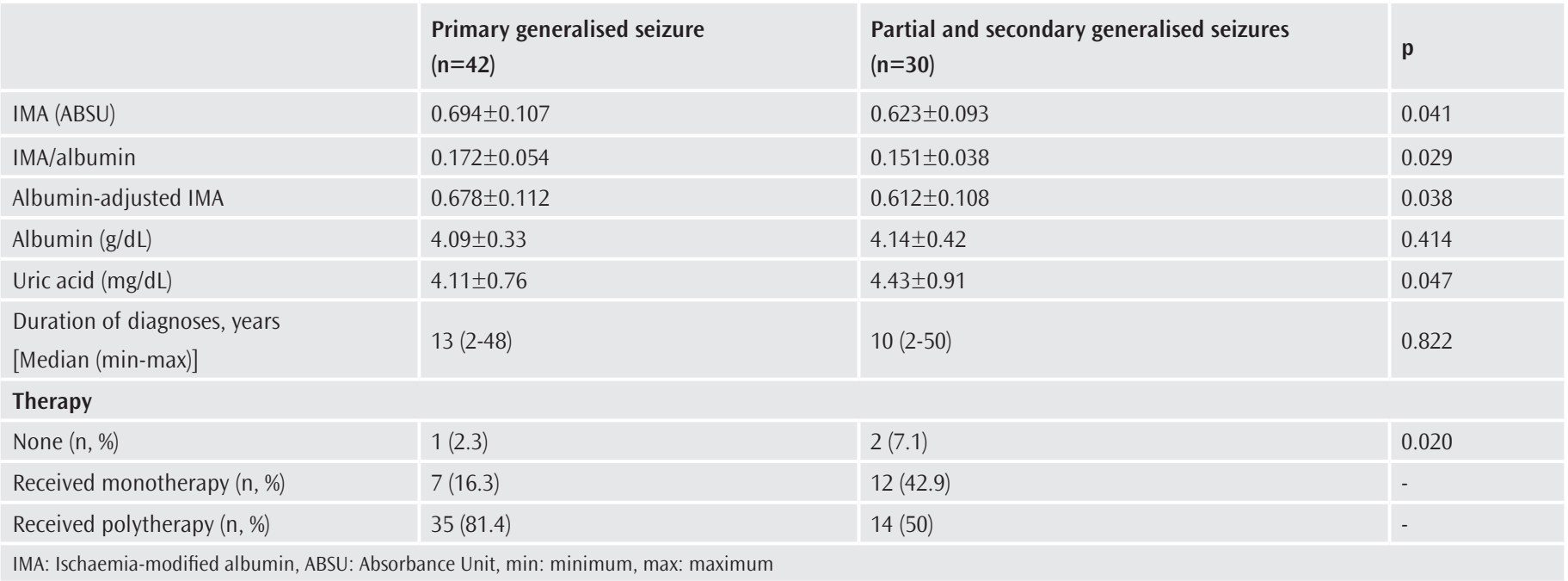


inflammatory state. However, IMA, IMA/Albumin index and Albuminadjusted IMA may help clinicians to differentiate the types of epilepsies.

\section{Ethics}

Ethics Committee Approval: The study was approved by the Ankara Numune Training and Research Hospital Ethics Committee with protocol number: 17-1439 (date: 05.07.2017).

Informed Consent: Informed volunteer consent was obtained from each patient.

Peer-review: Externally peer-reviewed.

Authorship Contributions: Concept - A.K., S.S., A.P.T., Z.N.Ö., T.T.; Design - A.K., S.S., C..Y., A.P.T., Z.N.Ö., T.T.; Data Collection or Processing - A.K., S.S., A.P.T.; Analysis or Interpretation - A.K., S.S., C..Y.; Literature Search A.K., S.S., A.P.T.; Writing - A.K., S.S., Ç.Y.

Conflict of Interest: No conflict of interest was declared by the authors.

Financial Disclosure: The authors declared that this study received no financial support.

\section{References}

1. Menon B, Ramalingam K, Kumar RV. Oxidative stress in patients with epilepsy is independent of antiepileptic drugs. Seizure 2012; 21: 780-4.

2. Kong Q, Lin CLG. Oxidative damage to RNA: mechanisms, consequences, and diseases. Cell Mol Life Sci 2010; 67: 1817-29.

3. Malinska D, Kulawiak B, Kudin AP, Kovacs R, Huchzermeyer C, Kann O, et al. Complex III-dependent superoxide production of brain mitochondria contributes to seizure-related ROS formation. Biochim Biophys Acta Bioenerg 2010; 1797: 1163-70.

4. Liang LP, Ho YS, Patel M. Mitochondrial superoxide production in kainateinduced hippocampal damage. Neuroscience 2000; 101: 563-70

5. Aguiar CCT, Almeida AB, Pontes Araújo PV, Cavalcante de Abreu RND, Chaves EMC, Cardoso do Vale 0, et al. Oxidative Stress and Epilepsy: Literature Review. Oxid Med Cell Longev 2012; 2012: 795259.

6. Eroğlu 0 , Türkmen $S$, Menteșe A, Altun $G$, Türedi S, Eryiğit U, et al. The diagnostic value of ischemia-modified albumin in the diagnosis of aortic pathology. Turk J Med Sci 2014; 44: 62-7.
7. Levine RL. Ischemia: From acidosis to oxidation. Faseb J 1993; 7: 1242-6.

8. Bar-Or D, Lau E, Winkler JV. A novel assay for cobalt-albümin binding and its potential as a marker for myocardial ischemia-a preliminary report. J Emerg Med 2000; 19: 311-5.

9. Bhagavan NV, Lai EM, Rios PA, Yang J, Ortega-Lopez AM, Shinoda H, et al. Evaluation of human serum albümin cobalt binding assay for the assessment of myocardial ischemia and myocardial infarction. Clin Chem 2003; 49: 581-5.

10. Roy D, Quiles J, Sharma R, Sinha M, Avanzas P, Gaze D, et al. Ischemia modified albümin concentrations in patients with peripheral vascular disease and exercise-induced skeletal muscle ischemia. Clin Chem 2004; 50: 1656-60.

11. Troxler M, Thompson D, Homer-Vanniasinkam S. Ischaemic skeletal increases serum ischemia modified albumin. Eur J Vasc Endovasc Surg 2006; 31: 164-9.

12. Kamaşak T, Türedi S, Serin HM, Menteșe A, Gündüz A, Alver A, et al. Can ischemia-modified albumin be used to differentiate between generalized seizures and pseudoseizures? Turk J Med Sci 2017; 47: 282-6.

13. Christenson RH, Duh SH, Sanhai WR, Wu AH, Holtman V, Painter P, et al. Characteristics of an Albumin Cobalt Binding Test for assessment of acute coronary syndrome patients: a multicenter study. Clin Chem 2001; 47: 464-70.

14. Temkin NR. Antiepileptogenesis and seizure prevention trials with antiepileptic drugs: meta-analysis of controlled trials. Epilepsia 2001; 42: 515-24.

15. Mareš J, Stopka P, Nohejlová K, Rokyta R. Oxidative stress induced by epileptic seizure and its attenuation by melatonin. Physiol Res 2013; 62(Suppl 1): S6774 .

16. Inci A, Gencpinar P, Orhan D, Uzun G, Ozdem S, Samur AA, et al. Ischemiamodified albumin levels in children having seizure. Brain Dev 2013; 35: 84952.

17. Patsoukis N, Zervoudakis G, Georgiou CD, Angelatou F, Matsokis NA, Panagopoulos NT. Effect of pentylenetetrazole-induced epileptic seizure on thiol redox state in the mouse cerebral cortex. Epilepsy Res 2004; 62: 65-74.

18. Tan DX, Manchester LC, Reiter RJ, Qi W, Kim SJ, El-Sokkary GH. Melatonin protects hippocampal neurons in vivo against kainic acid-induced damage in mice. J Neurosci Res 1998; 54: 382-9.

19. Willmore LJ, Triggs WJ, Gray JD. The role of iron-induced hippocampal peroxidation in acute epileptogenesis. Brain Res 1986; 382: 422-6. 